\title{
Sosialisasi dan Edukasi Protokol Kesehatan Bagi Masyarakat Desa
}

\author{
Desmira $^{1}$ \\ 1,Program Studi Pendidikan Vokasional Teknik Elektro, Fakultas Keguruan dan Ilmu Pendidikan \\ *e-mail: desmira@untirta.ac.id
}

\begin{abstract}
Community service activities carried out in Padarincang village are aimed at increasing public knowledge about the importance of maintaining health during the Covid 19 period, in this transitional period, education also changes things that need attention. The final target of this activity is that the community understands the importance of maintaining health and the impact on education during the Covid 19 period, the community becomes more aware of the current education patterns. In the event using google meet media, the event was divided into 2 speaker sessions related to the pattern of discussion about the education period during the Covid period, 19 of whom discussed the socialization of health protocols. In this event the participants who took part were mostly the people around the padarincang area, which was the main objective. This activity was assisted by the KKM 18 UNTIRTA group. The methods used are observation, interview and seminar. The results obtained from this activity are that the community understands the importance of maintaining health during Covid 19 and understands the current government regulations regarding the implementation of education. From the evaluation at the end of the seminar 96\% of the activities carried out were successful in accordance with the expected targets and achievements.
\end{abstract}

Kata kunci: Education during the Covid 19 period, socialization of health protocols, Google Meet

\begin{abstract}
Abstrak
Kegiatan pengabdian pada masyarakat yang dilakukan di desa padarincang ini adalah bertujuan untuk meningkatakan pengetahuan masyarakat tentang pentingnya menjaga kesehatan di masa Covid 19 ini dalam masa transisi ini pendidikan juga merubahan hal yang perlu diperhatikan. Target akhir dari kegiatan ini adalah masyakat faham akan pentingnya menjaga kesehatan dan dampak terhadap pendidikan masa covid 19 masyarakat menjadi lebih paham tentang pola pendidikan yang berlangsung pada saat ini. Dalam acara yang menggunakan media google meet ini acara dibagi menjadi 2 sesi pembicara yang berkaiatan dengan pola pembahasan tentang masa pendidikan dimasa covid 19 pembicara satunya membahas tentang sosialisai protokol kesehatannya. Dalam acara ini peserta yang ikut rata - rata adalah masyarakat di sekitar wilayah padarincang yang menjadi tujuan utamanya. Kegiatan ini dibantu oleh kelompok KKM 18 UNTIRTA. Metode yang digunakan adalah observasi, wawancara dan pelaksanaan seminar . hasil yang didapat dari kegiatan ini adalah masyarakat paham akan pentingnya menjaga kesehatan semasa covid 19 dan paham akan peraturan pemerintah tentang pelaksanaan pendidikan saat ini. Dari evaluasi yang diakhir seminar 96 $\%$ dari kegiatan yang dilaksanakan berhasil sesuai dengan target dan capaian yang diharapkan.
\end{abstract}

Keywords: Pendidikan di masa Covid 19, Sosialisasi Protokol kesehatan, Google Meet

\section{PENDAHULUAN}

Kecamatan Padarincang Kabupaten Serang-Banten adalah daerah yang memiliki beragam tempat wisata alam yang sangat berpotensi dikembangkan untuk peningkatan ekonomi masyarakat sekitar mulai dari Wisata Air Terjun Curug Cigumawang, Wisata Tubing dan permainan alam Cikal Adventure, Pemandian Air panas batukuwung, Pemandian Air Cirahab, Curug Cikotak dan Bukit Farm Waru Wangi. Selain itu, Padarincang memiliki Insfratruktur jalan yang sangat bagus untuk menunjang akses wisata tersebut. Selain menyimpan kekayaan wisata Kecamatan Padarincang juga memiliki pusat Ekonomi masyarakat yakni Pasar Padarincang yang setiap Dua kali dalam seminggu (Senin dan Kamis) selalu dipadati oleh pedagang dan masyarakat. Dimana kegiatan ekonomi yang terus berputar diharapkan selalu menjadi penopang ekonomi bagi masyarakat kecil di kecamatan Padarincang. Kondisi kecamatan Padarincang saat masa pandemi covid-19 seperti sekarang ini tidak terlalu terdampak baik itu secara ekonomi karena segala aktifitas ekonomi masih berjalan seperti biasanya tetapi sangat terdampak secara Pendidikan Karena sekolah-sekolah yang berada di daerah padarincang belum bisa melakukan pembelajaran tatap muka secara efektif. Selain Kecamatan Padarincang, KKM Kelompok 18 berlokasi di 
Kecamatan Pabuaran. Hal ini terjadi karena anggota kelompok 18 berasal dari kecamatan tersebut. Kecamatan Pabuaran adalah salah satu dari 29 kecamatan di Kabupaten Serang. Kecamatan Pabuaran Terletak disebelah selatan Kab. Serang. Pada awalnya Kecamatan Pabuaran adalah pemekaran dari Kecamatan Ciomas pada saat itu dibawah Keresidenan Banten dan Kewedanan Ciomas, akan tetapi seiring berjalanya waktu Kecamatan Pabuaran dimekarkan dengan Kecamatan Gubungsari. Kecamatan Pabuaran memiliki luas wilayah \pm 4042 Ha, dan jumlah penduduk 40216 Jiwa. Masyarakat Kecamatan Pabuaran Kabupaten Serang Secara Umum bermata Pencaharian Petani dan buruh Tani, disamping sebagian ada yang menjadi pengusaha, PNS, TNI, POLRI dan lainnya. Agama yang dianut mayoritas (100\%) Islam dengan banyaknya Pengajian Baik di Tingkat kecamatan, Desa dan Kampung, bahasa yang digunakan adalah bahasa Sunda (Serang) dan Bahasa Jawa (Serang), kultur dan budaya yang berkembang di masyarakat kecamatan Pabuaran sangat dipengaruhi kegiatan keagamaan diantaranya Maulidan, Jamiatu Syahriah, Rajaban dan Haul, pada umumnya budaya masyarakat di kecamatan Pabuaran tidak banyak jauh beda dengan kecamatan lain di kabupaten Serang. Seni Budaya Budaya yang berkembang di Pabuaran Adalah pencak Silat, Debus, Marawis, Kosidah Rudat dan lainnya.

Kegiatan KKM yang dilaksanakan selama 30 hari dan masuk dalam kurikulum mata kuliah wajib tempuh dengan bobot tiga sampai empat SKS merupakan salah satu bentuk pengamalan Tri Dharma Perguruan Tinggi dalam bidang Pengabdian pada Masyarakat yang dalam pelaksanaannya mencoba untuk mengabdikan diri di tengah-tengah kehidupan masyarakat luas dengan berbagai kompleksitas permasalahannya khususnya permasalahan covid-19 sehingga setahap demi setahap dapat meringankan beban masyarakat dan sekaligus dapat memeberikan motivasi kepada masayarakat agar masyarakat bisa terbiasa hidup dalam kondisi New Normal yaitu masyarakat yang tetap beraktifitas dengan protokol kesehatan sehingga menjaga masyarakat baik mental spiritual serta lahir dan batin. Mahasiswa sebagai agent of change (agen perubah) haruslah memiliki rasa tanggap sosial (Self Social Awarness) yang tinggi dan dosen yang mendampingin kegiatan pengabdian kepada masyarakat. Sebenarnya hakikat tanggung jawab seorang mahasiswa dan dosen telah jelas termaktub dalam Tri Dharma Perguruan Tinggi. Disini jelas disebutkan bahwa tugas mahasiswa adalah belajar, meneliti dan mengabdi pada masyarakat. Hendaknya dalam setiap waktu kehidupan dengan berbekal analisa berpikir kritis dan analogis mahasiswa mampu berkontribusi dengan pemikiran, tindakan dan praktik nyata dalam upaya perbaikan masyarakat terutama dalam proses pembangunan yang berkualitas sesuai ilmu pengetahuan dan teknologi dengan dilandasi iman dan takwa.

Sebagai kader-kader pembangunan yang masih ditempa di kampus Universitas Sultan Ageng Tirtayasa, sudah tentu bekal yang didapat hanya di kampus saja tidak cukup. Perlu banyak membangun pengalaman sebagai wujud nyata pengabdiannya dengan terjun langsung kepada masyarakat memberikan segala kemampuannya atau minimal dapat merasakan begitu besarnya harapan masyarakat terhadap keberadaan dan kemampuan mahasiswa. Terlebih saat ini keadaan masyarakat sedang di Landa bencana penyakit Novel Coronavirus atau yang lebih dikenal Covid19 yang berdampak ke berbagai sektor termasuk pendidikan dalam hal ini Pengabdian kepada masyarakat yang harus dilakukan dari rumah masing-masing mahasiswa demi menjaga keselamatan dan kesehatan masyarakat, Kuliah Kerja Mahasiswa Kali ini dilakukan dengan metode pendekatan yang berbeda dari biasanya dimana mahasiswa dituntut untuk melakukan pengabdian dengan Daring menggunakan akses internet sebagai fasilitas untuk mengabdi kepada masyarakat. Mahasiswa dikembalikan kepada kecamatan masing-masing dimana mahasiswa itu berasal, jadi mahasiswa dituntut untuk mengambil bagian untuk memberikan dampak positif disekitar daerah mahasiswa. Kelompok 18 KKM dan dosen Universitas Sultan Ageng Tirtayasa terbagi dari dua kecamatan yang masuk kedalam wilayah kabupaten Serang-Banten yakni kecamatan padarincang dan kecamatan Pabuaran. Dengan adanya sosialisasi edukasi protocol kesehatan bagi masyarakat desa dengan memanfaatkan Google Meet didesa diharapkan dapat memberikan kontribusi positif pentingnya mematuhi protocol kesehatan terutama di desa padarincang dan papuaran. Hal ini dilakukan padarincang dan pabuaran merupakan salah satu tujuan objek wisata bagi masyarakat yang ingin menikmati keindahan alam padarincang secara lebih dekat. Disamping sebagai objek wisata padarincang juga merupakan sentral pasar 
tradisional yang perlu dan penting dilakukan sosialisasi protocol kesehatan, sehingga mengurangi penyebaran virus covid 19 pada saat ini.

\section{METODE}

Metode yang digunakan adalah :

1) Tahap I (Observasi )

Pada tahap pertama ini observasi yang dilakukan oleh mahasiswa dan dosen berkunjung ke daerah padarincang dan pabuaran dengan silahturami ke tingkat desa dan kecamatan

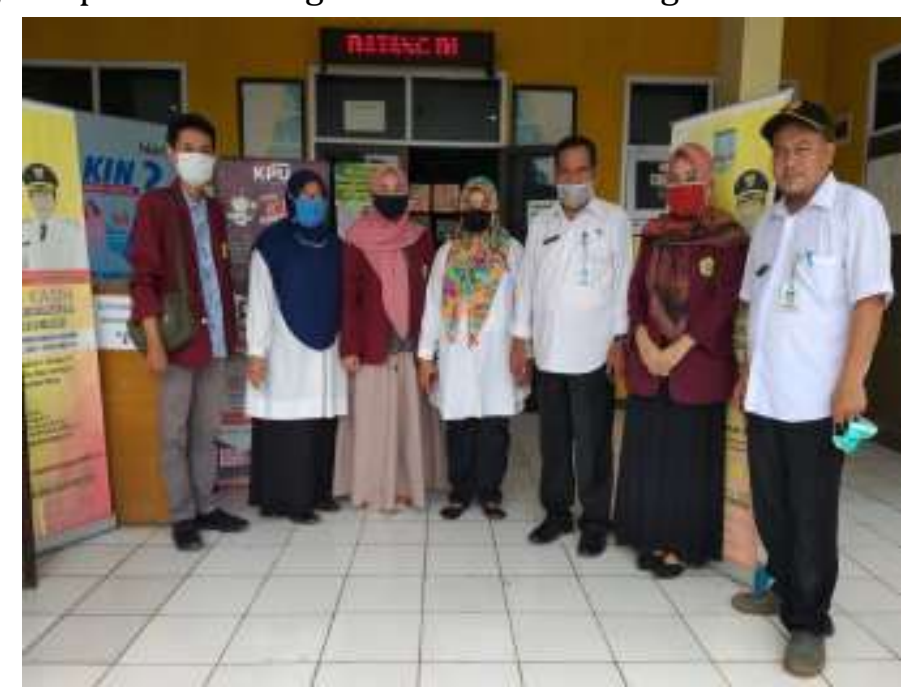

Gambar 1. Silahurahmi dengan perangkat desa padarincang dan pabuaran

2) Tahap II (Penyebaran Pamlet)

Pada tahap ini penyebaran pamlet baik kemasyarakat secara dor to dor ataupun secara menyebarkan lewat media social seperti Whathshap Group atau melalui media metsos lainnya.

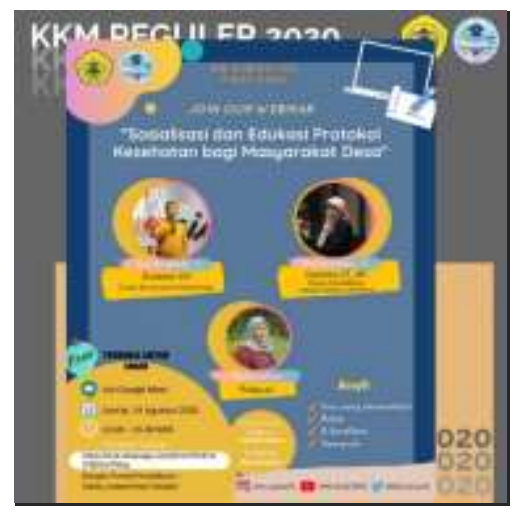

Gambar 2. Pamflet Kegiatan Seminar Menggunakan Google Meet

Materi pertama membahas tentang sosialisasi pentingnya menjaga kesehatan bagi masyarakat disaat Covid 19, disesi kedua membahas tentang sosialisasi peraturan pemerintah tentang 
pendidikan dimasa pandemi saat ini serta menjabarkan pelaksanaan daring yang dilakukan di dunia pendidikan saat ini

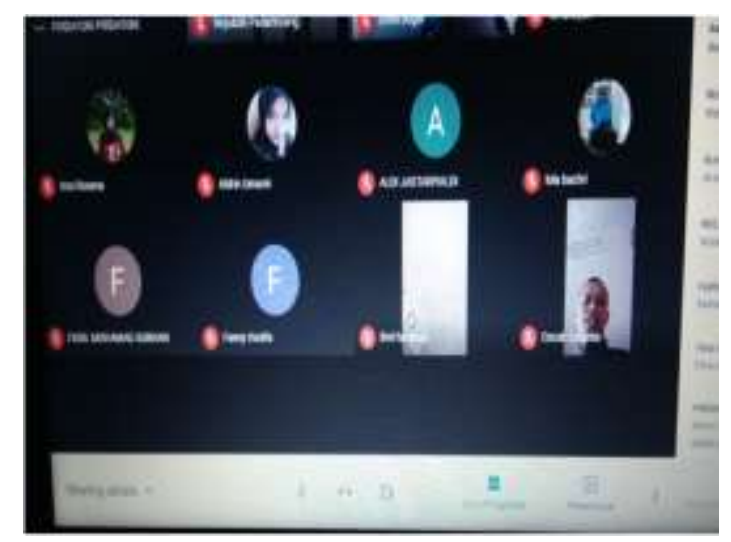

Gambar 3. Peserta seminar yang sedang mengikuti acara melalui google meet https://meet.google.com/cpp-cigv-geb

\section{HASIL DAN PEMBAHASAN}

Pelaksanaan ada pengabdian masyarakat yang dilakukan oleh mahasiswa dan dosen dari berbagai Latar Pendidikan Yang berbeda yang ada di Untirta. Sasaran utama dalam kegiatan yang dilakukan dengan melibatkan mahasiswa ini adalah masyarakat umum yang ada di padarincang dan pabuaran . Masyarakat yang terhubug dalam kegiatan ini 50 orang penduduk desa yang berada di padarincang dan pabuaran tersebut. Terdiri dari 30 orang ibu rumah tangga selebihnya adalah para pelajar mulai dari tingkat SLTP dan SMA.

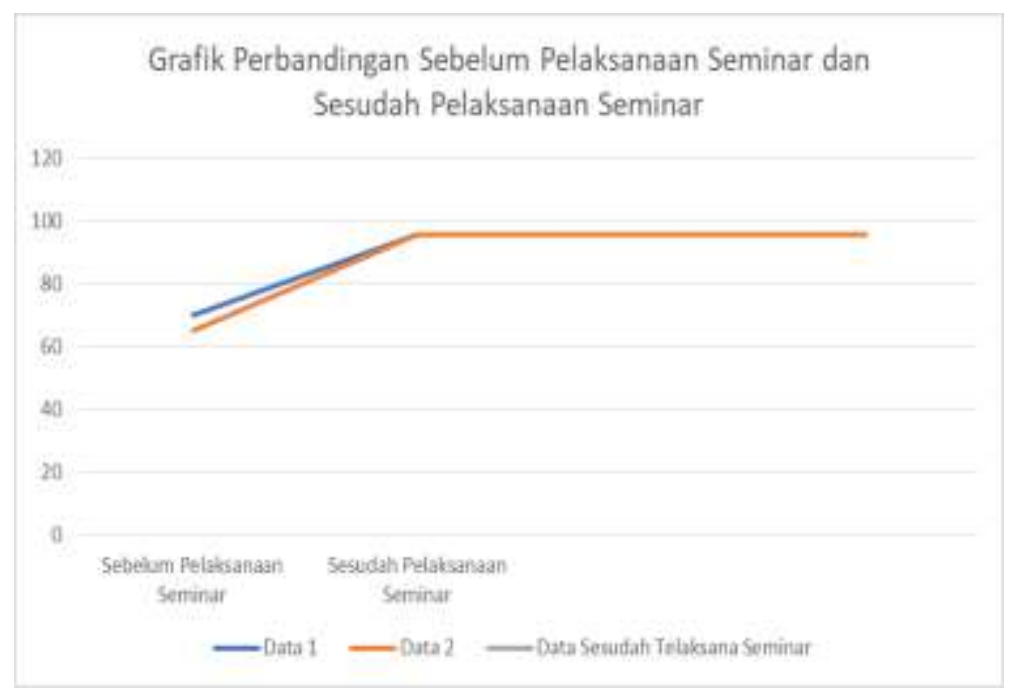

Gambar 3. Hasil test tingkat pemahaman masyarakat sebelum diadakan seminar(70\% dan 65\%) hasil evaluasi peserta seminar setelah seminar rata-rata test $96 \%$

\section{KESIMPULAN}

Dari Kegiatan pengabdian kepada masyarakat dengan melibatkan mahasiswa dan dosen berjalan dengan sukses hal ini ditandai dengan banyaknya peserta yang ikut 50 orang, terdiri dari masyarakat dan pelajar yang ada disekitar padarincang dan pabuaran. Diakhir kegiatan mahasiswa dan dosen juga melakukan evalusi dengan mengajukan beberapa pertanyaan hampir $96 \%$ dari peserta merasa senang dengan diadakan acaranya seminar menggunakan google meet. 
Dengan diadakan seminar dengan menggunakan google meet ini masyarakat yang awalnya tidak mengetahui pentingnya menjaga kesehatan dan mematuhi protocol kesehatan selama covid 19 ini menjadi lebih paham lagi tentang pentingnya mematuhi protokol kesehatan selama covid 19. Hal ini dapat dilihat dari evalusi yang diadakan setelah seminar.

\section{UCAPAN TERIMA KASIH}

Penulis mengucapkan terima kasih kepada Pemerintah Kecamatan Padarincang yang telah menerima peserta KKM, Universitas Sultan Ageng Tirtayasa Tahun 2020 Kelompok 18 yang berasal dari daerah Kecamatan Padarincang dan Kecamatan Pabuaran. Dr.Rusmana,.Ir.,MP yang telah memberikan kesempatan untuk saya membimbing mahasiswa KKM Reguler Universitas Sultan Ageng Tirtayasa Tahun 2020. Serta semua pihak mahasiswa KKM kelompok 18 Universitas Sultan Ageng Tirtayasa Tahun 2020 yang telah terlibat langsung dalam pelaksanna KKM regular .

\section{DAFTAR PUSTAKA}

Ade Nasihudin Al Ansori. (2020). Belajar di Rumah Akibat Corona COVID-19, Ini Pendapat dan Harapan Anak Indonesia. Liputan6. https://m.liputan6.com/health/read/4224969/belajardi-rumah-akibat-corona-covid-19-ini-pendapat-dan-harapan-anak-indonesia

Ashari, M. (2020). Proses Pembelajaran Daring di Tengah Antisipasi Penyebaran Virus Corona Dinilai Belum Maksimal. PikiranRakyatcom. https://www.pikiranrakyat.com/pendidikan/pr-01353818/proses-pembejalaran-daring-di-tengah-antisipasipenyebaran-virus-corona-dinilai-belum-maksimal

Menteri Pendidikan. (2020). Surat Edaran Nomor 3 Tahun 2020 Tentang Pelaksanaan Pendidikan dalam Masa Darurat CoronaVirus (COVID-19).

Hermansyah, dkk (2021). Peranan Peserta KKN Tematik Dalam Meningkatkan Kepatuhan Penggunaan Masker Pada Masa Pendemik Covid-19 di Kota Kendari. DINAMISIA: Jurnal Pengabdian Kepada Masyarakat Vol. 5, No. 1 Februari 2021, Hal. 181-187.

Pengelola Web Kemendikbud. (2020). Kemendikbud Imbau Pendidik Hadirkan Belajar Menyenangkan Bagi Daerah yang Terapkan Belajar di Rumah. Www.Kemendikbud.Go.Id. https://www.kemdikbud.go.id/main/blog/2020/03/kemendikbud-imbau-pendidikhadirkan-belajar-menyenangkan-bagi-daerah-yang-terapkan-belajar-di-rumah

Sobron, A. ., Bayu, Rani, \& Meidawati. (2019). Persepsi Siswa Dalam Studi Pengaruh Daring Learning Terhadap Minat Belajar IPA. SCAFFOLDING: Jurnal Pendidikan Islam Dan Multikulturalisme.

Silvi, A.D.M, dkk ( 2021 ). Sosialisasi Cara Berinteraksi melalui Video dan Banner Sebagai Upaya Pencegahan COVID-19. DINAMISIA: Jurnal Pengabdian Kepada Masyarakat Vol. 5, No. 1 Februari 2021, Hal. 241-252

Surat Edaran Kementerian Pendidikan dan Kebudayaan (Kemendikbud) Direktorat Pendidikan Tinggi No. 1 Tahun 2020

Suryawan, O. (2020). Guru Diminta Aktif Awasi Pembelajaran Daring Agar Siswa Tetap Fokus. BBALIPUSPANEWS.COM.

Tim, C. I. (2020). Corona, Kelas Daring, dan Curhat 2 Guru untuk Orang Tua. CNN Indonesia. https://m.cnnindonesia.com/gaya-hidup/20200330165053-284-488368/corona-kelasdaring-dan-curhat-2-guru-untuk-orang-tua

Wicaksono, V. D., \& Rachmadyanti, P. (2016). Pembelajaran Blended Learning melalui Google Classroom di Sekolah Dasar. Seminar Nasional Pendidikan PGSD UMS \& HDPGSDI Wilayah Timur.

Yurianto, Ahmad, Bambang Wibowo, K. P. (2020). Pedoman Pencegahan dan Pengendalian Coronavirus Disease (COVID-19) (M. I. Listiana Azizah, Adistikah Aqmarina (ed.). 